\title{
Contribution of bioturbation by the red swamp crayfish Procambarus clarkii to the recruitment of bloom-forming cyanobacteria from sediment
}

\author{
Yoshimasa YAMAMOTO \\ Division of Applied Biosciences, Graduate School of Agriculture, Kyoto University, Kyoto 606-8502, Japan \\ Present address: Research Center for Environmental Changes, Academia Sinica, 128, Sec. 2, Academia Rd., Taipei 11529, Taiwan \\ e-mail: yyama@rcec.sinica.edu.tw
}

\begin{abstract}
The development of cyanobacterial blooms in a small eutrophic pond was monitored along with the potential effect of bioturbation by the red swamp crayfish Procambarus clarkii discussed as well with respect to the recruitment of cyanobacteria from sediment. Cyanobacterial blooms were observed during the early spring and summer. The spring bloom was dominated by Aphanizomenon flos-aquae. Its population density reached the maximum level in late March, thereafter decreasing rapidly and becoming lower than the detection limit from May. When the water temperature exceeded $20^{\circ} \mathrm{C}$ in late May, the population density of Microcystis spp. began to increase, and a bloom was formed from July to early August. Anabaena spp. also contributed to the formation of the summer bloom. The population densities of both Microcystis spp. and Anabaena spp. began to decline in mid August. Crayfish were sampled using baited traps from April to November. No sample was obtained in April, whereas crayfish were captured constantly from May to November. They were distributed widely throughout the pond from June, although a large number of crayfish were captured most effectively at a particular point in the pond. The first captures in late May were dominated by males. The sex ratio of the captures was almost 1:1 from June to September, and fell in favor of females from October. The sex ratio reached a minimum (0.2:1) in mid November, when an extremely large number of crayfish were captured at a distinctly warm point. Next, the potential ability of crayfish to promote the recruitment of cyanobacteria from the sediment was examined by performing an incubation experiment. The presence of crayfish in containers of the pond sediment increased the densities of cyanobacteria such as Microcystis spp. and Anabaena spp. However, population densities of cyanobacteria began to decline after the crayfish was removed. Overall, bioturbation by crayfish seemed to be somewhat important in the dynamics of cyanobacterial blooms in the study pond; in addition, their effect varied with sex and season. Males may play an active role in the initiation of the bloom in late spring. Conversely, females may contribute to the extension of bloom in late autumn. Both males and females contribute equally to the maintenance of the bloom from summer to autumn.
\end{abstract}

Key words: bioturbation, cyanobacterial bloom, crayfish, recruitment of cyanobacteria, incubation experiment

\section{INTRODUCTION}

Cyanobacterial bloom formation in eutrophic lakes and ponds is a common phenomenon worldwide, and mechanisms of initiation and maintenance of the bloom have been extensively investigated. Cell division and recruitment from the sediment are the major factors contributing to the increase in cyanobacterial populations. As is well known, cell division or growth, is regulated by various factors, including nutrient concentration, irradiance and temperature. Laboratory studies have demonstrated that the growth of cyanobacteria is typically enhanced under a strong irradiance and at a high temperature in nutrient-rich conditions (Tsujimura \& Okubo 2003; Yamamoto \& Nakahara 2005a, b). Above results partially explain the development of cyanobacterial blooms in eutrophic environments from spring to summer.

Interestingly, the recruitment of cyanobacteria from sediment is also enhanced in analogous environments that favor the growth of cyanobacteria or bloom formation, such as a low N:P ratio (Ståhl-Delbanco et al. 2003), a strong irradiance (Barbiero 1993; Rengefors et al. 2004) and high temperature (Brunberg \& Blomqvist 2003; Karlsson-Elfgren \& Brunberg 2004; Verspagen et al. 2005). These findings may complicate the identification of which factor, i.e. either growth or recruitment, is more responsible for the increase in the planktonic population of cyanobacteria. The extent to which recruited cyanobacterial colonies or trichomes contributes to the increase in planktonic populations has often been viewed as extremely minor (Reynolds et al. 1981; Trimbee \& Harris 1984; Hansson et al. 1994; Head et al. 1999; Brunberg \& Blomqvist 2003; Karlsson-Elfgren et al. 2003; Ståhl-Delbanco et al. 2003; KarlssonElfgren \& Brunberg 2004). However, the recruited cyanobacteria can contribute to the increase in planktonic populations by not only recruitment per se, but also following cell division. Once benthic populations have been recruited to the water column, they cannot be distinguished from that overwintered as plankton, unless ex-benthic colonies are marked (Preston et al. 1980). Furthermore, previous works have investigated the recruitment of cyanobacteria from the sediment using various traps (Tan et al. 2008), which apparently have reduced the effect of the water current and prevented the 




Fig. 1. Map of Hirosawa-no-ike Pond showing sampling stations. Dotted area represents reed bed of Phragmites australis (Cav.) Trin. ex. Steud. Arrows show the direction of water flow.

intrusion of zoobenthos; as is well known, wind-driven current and bioturbation can enhance the resuspension of benthic populations of microorganisms to the water column (Schelske et al. 1995; Ståhl-Delbanco \& Hansson 2002; Verspagen et al. 2004). Consequently, most studies seem to have misunderstood the role of benthic populations, thus likely underestimating the contribution of benthic populations to bloom formation. Elucidating the formation of cyanobacterial blooms warrants reconsidering the importance of benthic populations as inocula for planktonic populations.

This study explores the possible effect of bioturbation by crayfish on the recruitment of bloom-forming cyanobacteria from sediment. Crayfish are representative macro zoobenthos in numerous freshwater ecosystems globally, owing to both natural distribution and artificial transplantation (Huner 2002; Taylor 2002). Their main habitat is generally the sediment surface, and so their activity, such as crawling and burrowing, inevitably cause sediment resuspension. Therefore, although these functions are reasonably assumed to enhance the recruitment of cyanobacterial colonies or trichomes from the sediment, the relationship between crayfish-associated bioturbation and the formation of cyanobacterial blooms has seldom been addressed. This study thus attempts to elucidate this relationship by performing a field survey and incubation experiment. In the field survey, seasonal succession of cyanobacteria and horizontal distribution of crayfish were investigated. Moreover, whether crayfish can potentially enhance the recruitment of cyanobacteria from the sediment was examined by performing an incubation experiment.

\section{METHODS}

\subsection{Study site}

Hirosawa-no-ike Pond (surface area $=14$ ha, mean depth $=1 \mathrm{~m}$ ) is an irrigational fish pond in Kyoto, Japan
(Fig. 1). This pond is classified as eutrophic with a periodic outbreak of heavy cyanobacterial blooms annually. The water is discharged from the pond in November to harvest the cultivated fish (carp, crucian carp and gudgeon). Nearly all of the sediment is exposed to air from December to mid-February when the water is reintroduced for the new fish culture. In such a unique environment, dormant cyanobacterial colonies or resting spores are assumed to serve as inocula for the development of the bloom (Yamamoto 2009b).

\subsection{Water sampling}

The Hirosawa-no-ike Pond was monitored almost biweekly from 17 February to 24 November in 2007. The surface water temperature was measured at the wharf (Station F, 3501'31.1"N, 135²4'28.4"E, see Fig. 1) at around 11:00. Each surface water sample was collected using a $250 \mathrm{~mL}$ plastic bottle, and brought to the laboratory within 1 hour. However, when crayfish sampling, as described below, was performed on the same day, the water sample was stored in a cool box. Population densities of cyanobacteria were determined under an inverted microscope (Nikon ECLIPSE TE300).

\subsection{Crayfish in Hirosawa-no-ike Pond}

The red swamp crayfish Procambarus clarkii (Girard 1852) is native to North America and was introduced in Japan in 1927. It subsequently spread rapidly across the country and is now regarded as a common zoobenthos, especially in small ponds and rivers. Although exactly when the red swamp crayfish began to inhabit Hirosawa-no-ike Pond is unknown, it has lived in the pond for at least four decades (Matsui, personal communication). In the pond, the red swamp crayfish is the representative benthic macroinvertebrate along with the freshwater shrimp Palaemon paucidens De Haan, 1844. The biomass of the red swamp crayfish likely 
exceeds that of freshwater shrimp, as inferred from very few of the latter that entered baited traps (data not shown). For convenience, the red swamp crayfish is simply referred to below as crayfish since only one species of crayfish lives in this pond.

\subsection{Crayfish sampling}

Crayfish were caught using a rectangular parallelepiped-shaped trap $(25 \mathrm{~cm} \times 25 \mathrm{~cm} \times 36 \mathrm{~cm})$ that comprised a net (mesh size $2 \mathrm{~mm}$ ) and wire. The trap contains a small bag in which bait is put and two opposite entrances $(\varnothing 6.5 \mathrm{~cm})$. This trap was applied in this study because it catches crayfish almost selectively without injuring or weakening them. Dried squid (the traditional diet in East Asia) was used as bait. Sampling was performed once to four times monthly from April to November 2007. The distribution pattern of the crayfish was evaluated by setting six traps at the nearshore and offshore stations (A-F, Fig. 1) between 12:00 and 13:00, and then raising them one hour later. However, seven traps were used on 17 November, on which day sampling was performed at seven stations $(A-G)$. Sampling positions were located using a portable global positioning device FG-530 (Empex Instruments, Tokyo, Japan). Supplementary samplings were performed several times at station $\mathrm{F}$ after the regular sampling had been completed, or on other days, to collect as many samples as possible for statistical purposes. All captures were brought alive to the laboratory, and the sex, body length (from the back of the eye socket to the end of the telson) and body weight of each were recorded. The sex ratio of the captures was calculated when at least two males and two females were captured in synchronous samples.

\subsection{Recruitment experiment}

An incubation experiment was performed to examine the potential impact of crayfish-associated bioturbation on the recruitment of cyanobacteria. Surface sediment was scooped with a dip net at the center of Hirosawa-no-ike Pond on 18 August 2007, and brought to the experimental farm $\left(35^{\circ} 01^{\prime} 47^{\prime \prime} \mathrm{N}, 135^{\circ} 47^{\prime} 03^{\prime \prime} \mathrm{E}\right)$ in the grounds of Kyoto University. Four plastic containers (I, II, III and IV; $40 \mathrm{~cm}$ long $\times 35 \mathrm{~cm}$ wide $\times 25 \mathrm{~cm}$ high) were placed next to each other. After $2 \mathrm{~kg}$ of sediment was placed in each container, one-day-old tap water was slowly poured into each container to a height of approximately $3 \mathrm{~cm}$ below the top of the container. To evaluate the effect of crayfish-associated bioturbation on the community structure of cyanobacteria in the water, four form I males captured on 18 August and stocked in running water were used. One animal was added or removed, according to the scheme in table 1 . Each container was covered with a wire sheet (mesh size $1 \mathrm{~cm}$ ) to prevent contamination by large foreign substances and the escape of the crayfish. Surface water temperatures in the containers were measured daily at noon from 19 August to 11 September using a mercury thermometer. Surface water was collected in $100 \mathrm{~mL}$ plastic bottles and brought to the laboratory within 5 min, where the population densities of Microcystis and Anabaena were determined under an inverted microscope. Crayfish were not fed throughout the experimental period.

Tab. 1. Presence or absence of crayfish in containers. Each circle represents the presence of a male crayfish.

\begin{tabular}{lccc}
\hline container & 19 Aug - 26 Aug & 26 Aug - 3 Sep & 3 Sep - 11 Sep \\
\hline I & & $\circ$ & \\
II & $\circ$ & $\circ$ & 0 \\
III & $\circ$ & 0 & \\
IV & $\circ$ & $\circ$ & $\circ$ \\
\hline
\end{tabular}

\section{RESULTS}

\subsection{Field surveys}

Surface water temperature tended upward from 31 March and exceeded $20{ }^{\circ} \mathrm{C}$ on 12 May (Fig. 2). After peaking at $32.7^{\circ} \mathrm{C}$ on 18 August, the temperature began to drop sharply, falling below $20^{\circ} \mathrm{C}$ after 20 October.

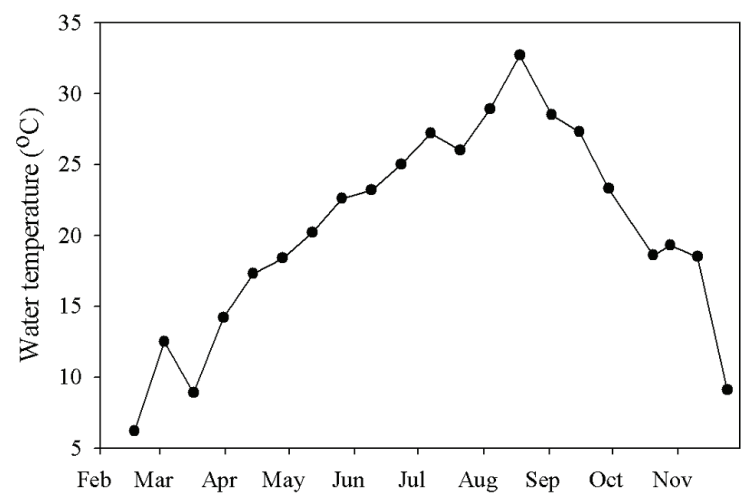

Fig. 2. Change in water temperature in Hirosawa-no-ike Pond.

Aphanizomenon flos-aquae var. klebahnii Elenk. was present in the water on 17 February and its population density increased rapidly to the maximum $(1.52 \times$ $10^{4}$ trichomes $\mathrm{mL}^{-1}$ ) on 31 March, after which it decreased rapidly (Fig. 3A). The net growth rates of $A p$. flos-aquae, as obtained by fitting a least-square linear regression with the natural logarithm of trichome density from 17 February to 31 March was $0.16 \mathrm{~d}^{-1}$ (Pearson's product moment correlation coefficient, $r^{2}=0.98$, $n=4, p<0.05$ ). Three Microcystis species, i.e. $M$. aeruginosa (Kütz.) Kütz., M. viridis (A.Br.) Lemm. and $M$. wesenbergii (Kom.) Kom. in N. V. Kondr., were detected already in February with relatively high densities (Fig. 3B). They started to increase from May. The net growth rates of $M$. aeruginosa, $M$. viridis and $M$. wesenbergii from 28 April (26 May for $M$. viridis) to 4 August were $0.075 \mathrm{~d}^{-1}\left(r^{2}=0.95, n=8, p<0.01\right), 0.065$ $\mathrm{d}^{-1}\left(r^{2}=0.69, n=6, p<0.05\right)$ and $0.078 \mathrm{~d}^{-1}\left(r^{2}=0.95, n\right.$ 
$=8, p<0.01)$, respectively. All Microcystis species reached their maximum on 4 August (M. aeruginosa: $4.50 \times 10^{5}$ colonies $\mathrm{mL}^{-1}, M$. viridis: $1.67 \times 10^{4}$ colonies $\mathrm{mL}^{-1}, M$. wesenbergii: $2.50 \times 10^{5}$ colonies $\mathrm{mL}^{-1}$ ), and then decreased sharply.
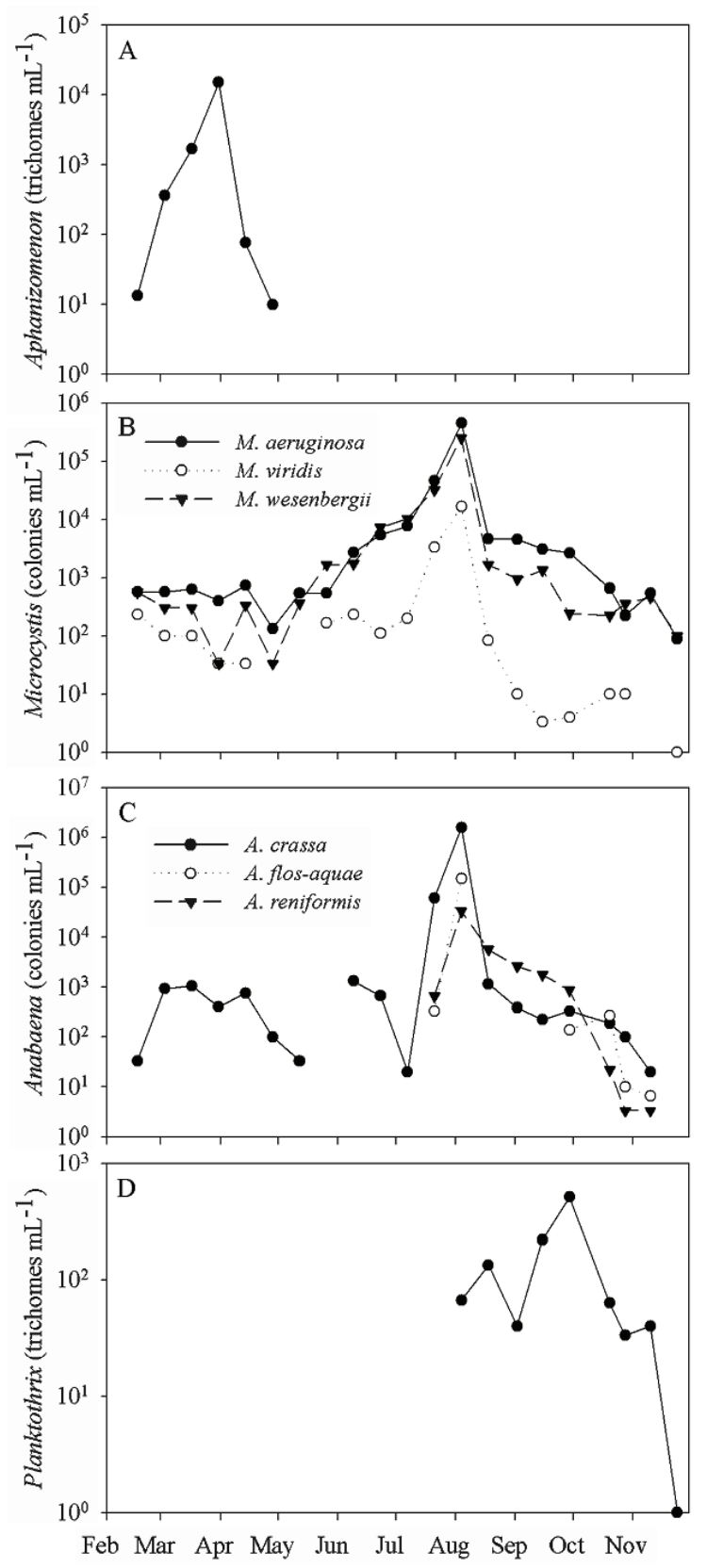

Fig. 3. Changes in abundance of Aphanizomenon flos-aquae (A), Microcystis spp. (B), Anabaena spp. (C) and Planktothrix raciborskii (D) in Hirosawa-no-ike Pond.

The natural-logarithms of the population density of Microcystis spp. were significantly correlated with water temperature $\left(r^{2}=0.46, n=21, p<0.001\right)$. Anabaena consisted of three representative species, i.e. $A n$. crassa (Lemm.) Kom.-Leg. \& Cronb., An. flos-aquae Bréb. ex Born. \& Flah. and An. reniformis Lemm. emend. Aptekar (Fig. 3C). An. crassa increased in March, and became undetectable during late May. It reappeared in June, reaching an extremely high density $\left(1.6 \times 10^{6}\right.$ trichomes $\left.\mathrm{mL}^{-1}\right)$ on 4 August, and then sharply declined. An. flos-aquae and An. reniformis appeared from mid-July. They reached maximum on 4 August and declined thereafter. Planktothrix raciborskii (Wolosz.) Anagn. \& Kom. appeared on 4 August and peaked on 29 September $\left(5.10 \times 10^{2}\right.$ trichomes $\left.\mathrm{mL}^{-1}\right)$, thereafter falling rapidly (Fig. 3D). Raphidiopsis mediterranea Skuja was present in the water only in September with a very low population density $(<1.43 \times$ $10^{2}$ trichomes $\mathrm{mL}^{-1}$ ) (data not shown).

Although the first attempt to sample crayfish was made on 28 April, no crayfish were captured (Tab. 2). The first crayfish were captured on the second attempts on 23 May; at that time, seven males and one female were captured. Subsequently, at least three crayfish were captured in each trial until 17 November. They were captured at stations A-F from June to November, but the number of captures at station $\mathrm{F}$ greatly exceeded those at other stations. Sampling at station G was performed only on 17 November, and the highest number of crayfish was captured at the time. The total number of the captures reached 278 (101 males and 177 females). The body length and body weight of males ranged from 41.4 to $82.4 \mathrm{~mm}$ with a mean of 64.2 $( \pm 7.72 \mathrm{SD}) \mathrm{mm}$ and from 2.36 to $28.7 \mathrm{~g}$ with a mean of $12.1( \pm 4.87 \mathrm{SD}) \mathrm{g}$, respectively (data not shown). In contrast, the body length and body weight of females ranged from 49.7 to $89.5 \mathrm{~mm}$ with a mean of 68.2 ( \pm $6.45 \mathrm{SD}) \mathrm{mm}$ and from 4.54 to $32.1 \mathrm{~g}$ with a mean of $13.6( \pm 4.26 \mathrm{SD}) \mathrm{g}$, respectively. The sex ratio of the captures varied with the season (Fig. 4). The captures on 23 May consisted of seven males and one female. The sex ratio did not significantly differ from 1:1 from June to September, but decreased significantly from 1:1 from October, falling gradually to the minimum $(0.20: 1)$ on 17 November. No oviferous female was captured throughout the study.

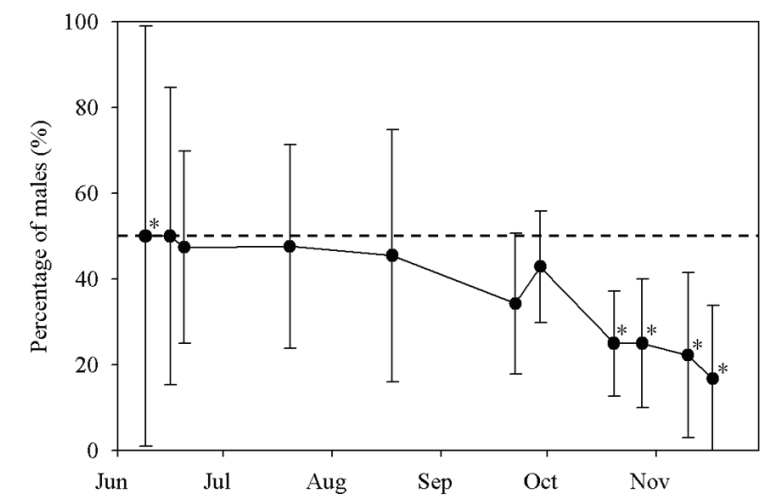

Fig. 4. Change in percentage of male crayfish. Dashed line represents percentage of males $=50 \%($ sex ratio $=1: 1)$. Error bars indicate $95 \%$ confidence intervals. *: Significantly different from $50 \%(p<0.05)$. 
Tab. 2. Number of crayfish captured hourly at each sampling station. Asterisks indicate supplementary samplings, using one trap (9 June and 23 June), three traps (22 September) and six traps (29 September, 20 October and 28 October). Numbers in parentheses are numbers of crayfish captured in regular samplings.

\begin{tabular}{lcccccccc}
\hline & A & B & C & D & E & F & G & Total \\
\hline 28 Apr & 0 & 0 & 0 & 0 & 0 & 0 & - & 0 \\
23 May & 0 & 4 & 0 & 0 & 0 & 4 & - & 8 \\
9 Jun* & - & - & - & - & - & 4 & - & 4 \\
16 Jun & 1 & 1 & - & 0 & 2 & 4 & - & 8 \\
20 Jun & 1 & 1 & 6 & 1 & 2 & 8 & - & 19 \\
23 Jun* & - & - & - & - & - & 3 & - & 3 \\
20 Jul & 0 & 2 & 3 & 3 & 3 & 10 & - & 21 \\
18 Aug & 5 & 0 & 4 & 0 & 1 & 1 & - & 11 \\
22 Sep & 2 & 1 & 0 & 2 & 3 & 8 & - & 16 \\
22 Sep* & - & - & - & - & - & 16 & - & 16 \\
29 Sep & 2 & 5 & 6 & 2 & 4 & 7 & - & 26 \\
29 Sep* & - & - & - & - & - & 30 & - & 30 \\
20 Oct & 0 & 4 & 1 & 1 & 6 & 5 & - & 17 \\
20 Oct* & - & - & - & - & - & 31 & - & 31 \\
28 Oct & 1 & 6 & 0 & 2 & 0 & 4 & - & 13 \\
28 Oct* & - & - & - & - & - & 19 & - & 19 \\
10 Nov & 7 & 2 & 4 & 3 & 0 & 2 & - & 18 \\
17 Nov & 1 & 1 & 2 & 0 & 0 & 1 & 13 & 18 \\
Total & 20 & 27 & 26 & 14 & 21 & $157(54)$ & 13 & $278(175)$ \\
\hline
\end{tabular}

\subsection{Recruitment experiment}

Four cyanobacteria species were detected in the sediment sample. The population densities of $M$. aeruginosa, $M$. viridis, $M$. wesenbergii and $A$. reniformis were 5220 colonies $\mathrm{g}^{-1}, 430$ colonies $\mathrm{g}^{-1}, 3040$ colonies $\mathrm{g}^{-1}$ and 140 trichomes $\mathrm{g}^{-1}$, respectively. The mean water temperature fluctuated between 24.7 and $28.9{ }^{\circ} \mathrm{C}$ from 19 August to 9 September, and decreased rapidly from 10 September to $20.7^{\circ} \mathrm{C}$ on 11 September (Fig. 5A).

The representative recruited cyanobacteria genera were Microcystis and Anabaena, which consisted of three (M. aeruginosa, $M$. viridis and $M$. wesenbergii) and two (An. crassa and An. reniformis) species, respectively. The population density of Microcystis ranged from 110 to 210 colonies $\mathrm{mL}^{-1}$ on 19 August, subsequently increasing to $960-1530$ colonies $\mathrm{mL}^{-1}$ on 20 August in the containers of crayfish (Fig. 5B). In contrast, it remained low $\left(<120\right.$ colonies $\left.\mathrm{mL}^{-1}\right)$ in containers that had no crayfish. The mean colony densities of Microcystis in containers with crayfish from 20 to 26 August significantly exceeded those in containers without crayfish (paired $t$-test, $n=7, p<0.001$ ). The same tendency was observed for Anabaena: the trichome densities of Anabaena in containers of crayfish from 20 to 26 August significantly exceeded those in containers without crayfish (paired $t$-test, $n=7, p<0.001$ ) (Fig. 5C). Newly adding crayfish to containers I and II on 26 August significantly increased the density of Microcystis colonies on 27 August. From 27 August to 3 September, the colony density of Microcystis in container II remained as high as those in containers III and IV, whereas that in container I fell gradually to a minimum (60 colonies $\mathrm{mL}^{-1}$ ) on 2 September. The recruit- ment of Anabaena was unremarkable and often below the detection limit after 27 August. The removal of crayfish on 3 September promoted the rate of drop in the density of Microcystis colonies in container I. In contrast, the Microcystis colony density in container III remained as high as that in container II until 8 September, but declined rapidly from 9 September. In all containers, $M$. aeruginosa accounted for $49.8-71.0 \%$ of the Microcystis population. The contribution of $M$. viridis was almost negligible, as it represented only $0.7-1.0 \%$. An. reniformis represented $71.9-86.2 \%$ of the Anabaena population.

\section{DISCUSSION}

\subsection{Dynamics of cyanobacteria}

Aphanizomenon flos-aquae was the only cyanobacteria species in the Hirosawa-no-ike Pond that grew in March when the water temperature was below $15^{\circ} \mathrm{C}$, implying that this species is adapted to low water temperatures. Some investigators have reported the dominance of Ap. flos-aquae during winter (Barbiero \& Welch 1992, Tsukada et al. 2006). However, according to previous studies, it frequently appears as a component of summer blooms (Pechar 1992; Takano \& Hino 2000; Yamamoto \& Nakahara 2005b, 2009a). Yamamoto (2009a) has reported that natural populations of Ap. flos-aquae can be divided into summer and winter types, depending on their season of optimal growth. The summer-type Ap. flos-aquae produces akinetes in response to the drop in water temperature and overwinters in the bottom sediment (Yamamoto \& Nakahara 2009a). The winter-type A. flos-aquae in Lake Yogo (Shiga, Japan) is present in the water throughout the year (Tsukada et al. 2006). Tsujimura et al. (2001) demonstrated that the winter-type Ap. flos-aquae, as 
isolated from Lake Biwa, has an optimal range of water temperature for growth between 23 and $29^{\circ} \mathrm{C}$, but it can grow even at $8{ }^{\circ} \mathrm{C}$, and can survive at $5{ }^{\circ} \mathrm{C}$, although its growth is suppressed. These results suggest that the winter-type Ap. flos-aquae, including the population in the study pond, can grow over a wide range of water temperatures as well as during the winter due to its tolerance of low temperature, rather than a preference for it.

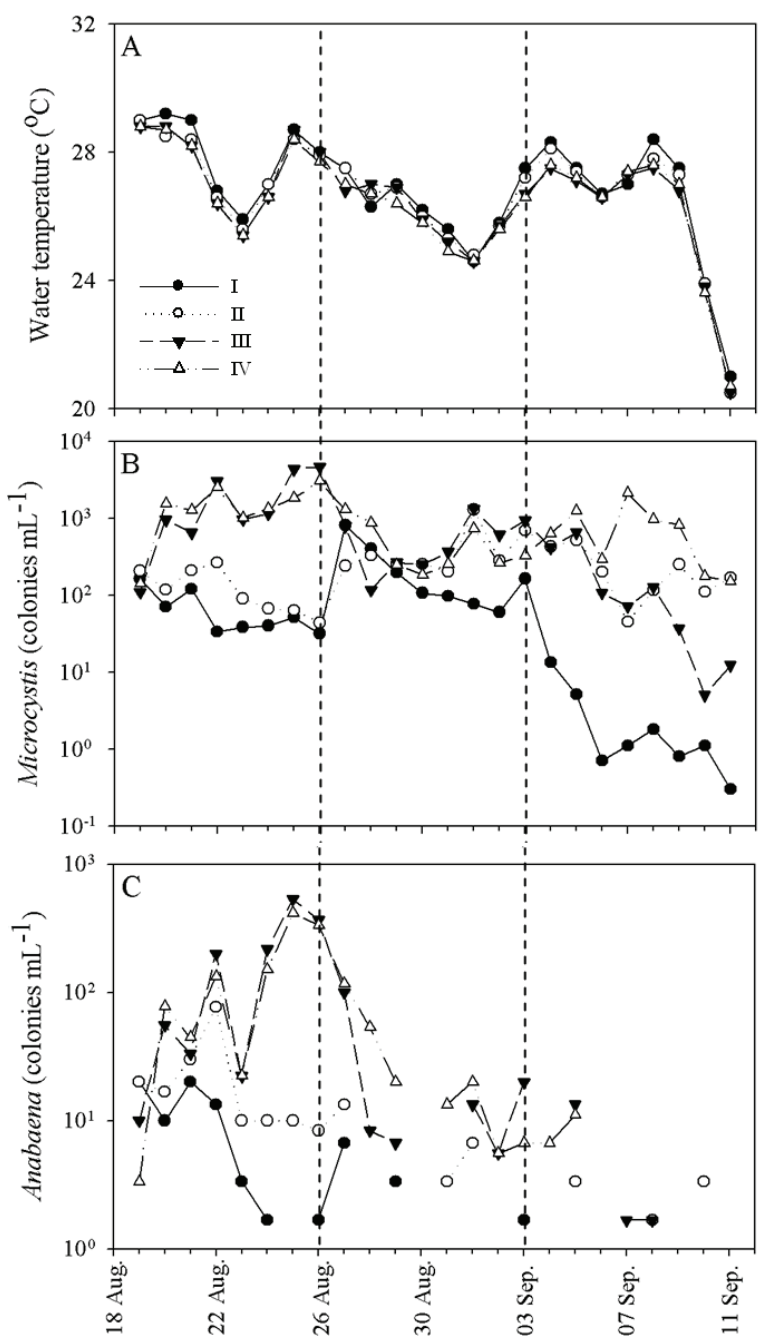

Fig. 5. Changes in water temperature (A) and abundance of Microcystis spp. (B) and Anabaena spp. (C) in each container. Vertical dashed lines represent days when crayfish was either added or removed (see Tab. 1).

Other cyanobacteria, such as Microcystis, Anabaena and $P$. raciborskii, reached their maximum densities in August or September when the water temperature exceeded $23{ }^{\circ} \mathrm{C}$, suggesting that they prefer high temperatures. In recent years, the typical seasonal pattern of cyanobacteria in Hirosawa-no-ike Pond has been the exclusive dominance of Microcystis until the early summer and the co-dominance of Microcystis and Anabaena during the summer, followed by the appearance of $P$. raciborskii (Yamamoto 2009a; Yamamoto \& Nakahara 2009b). The cyanobacteria in the water column are thought to originate in recruitment from the sediment (Yamamoto 2009b). Since all of Hirosawa-noike Pond is shallow, most of the pond sediment is a favorable source of cyanobacteria (Hansson 1996; Brunberg \& Blomqvist 2003; Karlsson-Elfgren \& Brunberg 2004). Temperature is an important factor that regulates the recruitment of cyanobacteria from the sediment (Tsujimura et al. 2000; Brunberg \& Blomqvist 2003; Karlsson-Elfgren \& Brunberg 2004; Ihle et al. 2005). Yamamoto (2009b) demonstrated that the recruitment of Microcystis from the sediment increases when the temperature exceeds $15{ }^{\circ} \mathrm{C}$. However, the population of Microcystis did not notably increase until May, despite the fact that water temperature exceeded $15{ }^{\circ} \mathrm{C}$ from April. The threshold temperature for the growth of Microcystis is around $15{ }^{\circ} \mathrm{C}$ (Robarts \& Zohary 1987; Tsukada 2006). Above results suggest that neither recruitment from the sediment nor the growth of Microcystis occurred, regardless of whether the temperature in April was suitable, although the cause remains uncertain. The population density of Microcystis began to increase when the water temperature exceeded $20^{\circ} \mathrm{C}$ in May.

Nitrogen concentration has an important role in the regulation of the cell buoyancy of cyanobacteria, and a limited concentration of nitrogen reduces buoyancy (Klemer et al. 1982; Spencer \& King 1989; Brookes \& Ganf 2001). Although this study did not monitor the seasonal change in nitrogen concentration, nitrogen deficiency in the pond from late spring to autumn has been typical in recent years, as the concentrations of $\mathrm{NH}_{4}{ }^{+}-\mathrm{N}, \mathrm{NO}_{2}{ }^{-}-\mathrm{N}$ and $\mathrm{NO}_{3}{ }^{-}-\mathrm{N}$ during this period often decrease below or close to the detection limit (Tsukada 2006; Yamamoto 2009a; Yamamoto \& Nakahara 2009b). Therefore, although temperature suffices for the recruitment of cyanobacteria, continuous resuspension of the sediment is assumed to be important not only in supplying cyanobacterial colonies or trichomes to the water column, but also in preventing them from sedimentation due to nitrogen deficiency. One of the important factors that contribute to sediment resuspension is the wind-driven water current, which promotes the recruitment of cyanobacteria from the sediment (Schelske et al. 1995). Another important factor is bioturbation by abundant animals, such as fish (Havens 1991; Matsuzaki et al. 2007) and benthic invertebrates (Ståhl-Delbanco \& Hansson 2002). Although less well studied, large zoobenthos, such as crayfish or crab may have a particularly strong effect on the resuspension of cyanobacteria and the sediment if they become dominant. In the case of Hirosawa-no-ike Pond, crayfish $P$. clarkii dominates the community of zoobenthos, and its continuous activity at the sediment, such as crawling, burrowing, feeding and fighting, may coincidentally facilitate the recruitment of cyanobacteria. 


\subsection{Behavior of crayfish}

Hirakoso (2001) observed three types of burrow of $P$. clarkii in a fallow rice field where the water management was analogous to that of Hirosawa-no-ike Pond, and supposed that the length of a burrow reflects the strategy of $P$. clarkii against sediment drying; they start to burrow more deeply below or closer to the level of groundwater in response to the drop in the water level in autumn. Therefore, crayfish in the study pond are assumed to remain in their burrows during winter when the pond sediment is exposed to air, and then appear in the water after the pond sediment has been covered with water. Since the burrows of $P$. clarkii are normally several tens of centimeters deep and occasionally over $1 \mathrm{~m}$ long (Hirakoso 2001) and that they offer thermally stable environments (Payette \& McGaw 2003), the temperature inside the burrow may have remained low in late April despite the fact that the temperature of the water column had already increased sufficiently for the crayfish to begin feeding (Croll \& Watts 2004). Therefore, the crayfish stayed in the bottom of their burrows until late May when the temperature there seemed to have increased sufficiently for them to become active (Suko 1958; Nyström 2002).

The captures were dominated by mature individuals, based on body size (Suko 1958). Previous studies indicated that adult crayfish are prone to be selectively captured by baited traps, and thus the size structure of captures may be biased toward large individuals with a dominance of males (Gherardi \& Barbaresi 2000; Dorn et al. 2005; Faller et al. 2006). However, the results of this study in terms of the sex ratio were not consistent with this finding, since the number of females frequently exceeded that of males and the sex ratio did not significantly differ from 1:1 at least between June and September. Notably, crayfish populations typically exist with a sex ratio of 1:1 (Reynolds 2002), explaining why information on the sex ratio of the captures is expected to reflect that of the natural population in the pond. The sex ratio of the captured crayfish varied with season; males dominated the captures in late May, and females dominated in October and November. These results may suggest that the seasonal pattern of activity of crayfish depends on sex, i.e. males are more active than females in spring whereas females can remain highly active for longer than the males in late autumn, and both males and females are equally active from early summer to autumn. However, the number of captures in August when the water temperature approaches the annual maximum was lower than those in the preceding or following month. This phenomenon appears to be owing to that many crayfish had dug burrows and remained there in August to avoid high temperatures (Nyström 2002).

As is well known, juvenile and adult crayfish have different habitat-use patterns; the former frequently appear in shallow areas, while the latter prefer deeper ones (Creed 1994; Englund \& Krupa 2000). The depths of stations A-E and $\mathrm{G}$ ranged from 0.6 to $1.0 \mathrm{~m}$ and these stations are relatively far from the shore; station $\mathrm{F}$ has a depth of $0.8 \mathrm{~m}$. These stations are assumed to be relatively deep in the pond and may not be suitable habitats for juveniles, possibly explaining the absence of juveniles with body lengths below $41.4 \mathrm{~mm}$ in the captures. In the Hirosawa-no-ike Pond, cyanobacteria exist in the sediment during the winter when the water is drained; they can successfully survive there if the water content of the sediment exceeds $40 \%$ (Yamamoto 2009b). The sediment in shallow areas is exposed to air for longer than in deep areas. Shallow areas are thus not conducive to the survival of cyanobacteria because they dry easily. Therefore, the recruitment of cyanobacteria in the study pond is inferred to occur primarily in deeper areas of the pond (which is only $1.8 \mathrm{~m}$ deep at its deepest point), and bioturbation by adult crayfish in deeper areas seems to be much more important than that by juveniles in shallower areas.

\subsection{Effect of bioturbation by crayfish on the recruitment of cyanobacteria}

The active feeding of crayfish from a wide range of food sources can strongly affect the structure of food webs (Nyström 2002). In particular, the substantial negative impact of $P$. clarkii on the diversity and structure of macrophytes has been well documented (Feminella \& Resh 1989; Anastácio et al. 2000; Smart et al. 2002; Rodríguez et al. 2003; Rodríguez et al. 2005). Rodríguez et al. (2003) noted that the propagation of $P$. clarkii caused the deterioration of the macrophytes in Lake Chozas in Spain, and that the main primary producers in the lake were replaced by Microcystis. Previous studies explain this phenomenon in at least two ways. First, the authors measured a high concentration of total phosphorus after the dominance of $P$. clarkii, which favors the dominance of cyanobacteria (Trimbee \& Prepas 1987; Downing et al. 2001). Second, the allelopathic influence of macrophytes no longer suppressed the growth of cyanobacteria (Nakai et al. 1999; Körner \& Nicklisch 2002). Additionally, the direct impact of crayfish through bioturbation also seems to be important. Crayfish can influence the microalgal populations directly or indirectly through the consumption of microalgae and invertebrate grazers, or nutrient excretion, whereas these effects are generally assumed to be insignificant (Nyström 2002). However, some investigators have reported the positive effect of bioturbation by $P$. clarkii in supplying nutrients from the sediment to the water column, which may promote the growth of phytoplankters (Angeler et al. 2001; Rodríguez et al. 2003). Moreover, the incubation experiment in the present study showed that $P$. clarkii can significantly promote the recruitment of cyanobacteria, and $P$. clarkii was extensively distributed in the study pond from June to November. These results, combined with the fact that $P$. clarkii can migrate a long 
distance within a short period (Gherardi \& Barbaresi 2000; Gherardi et al. 2000) and can dig many burrows by moving a large amount of sediment (Burras et al. 1995; Barbaresi et al. 2004), imply that bioturbation by $P$. clarkii can influence the development of summer blooms of cyanobacteria in waters in which $P$. clarkii is abundant, such as the Hirosawa-no-ike Pond.

Recruitment and growth are the primary mechanisms of the increase in the population densities of cyanobacteria, and both are usually enhanced at high temperatures. In Hirosawa-no-ike Pond, the seasonal dynamics of Microcystis cannot be explained by only growth, and the continuous recruitment of colonies from the sediment may be importantly involved in maintaining high densities of Microcystis during the summer and autumn (Yamamoto \& Tsukada 2009). Since the pond is shallow, the wind-induced water current appears to significantly impact the resuspension of sediment and cyanobacteria, despite the lack of available data. Additionally, crayfish-associated bioturbation may also contribute to the enhancement of the resuspension of benthic cyanobacterial colonies, while considering the effect of crayfish that facilitates the recruitment of cyanobacteria and the wide distribution of crayfish in the pond, as demonstrated in this study. Notably, the first samples of crayfish were captured on 23 May when the density of Microcystis began to increase. The number of captured crayfish on that day was small; however, seven out of eight were males. This finding suggests the possibility that males are generally more active than females during this period; bioturbation by male crayfish enhances the recruitment of cyanobacteria and thereby contributes to the initiation of the bloom. The sex ratio was almost 1:1 from June to September. Cyanobacterial bloom consisting of Microcystis, Anabaena and $P$. raciborskii occurred during this period, hence both male and female crayfish seem to contribute equally to the maintenance of the bloom by facilitating the recruitment of cyanobacteria from the sediment. However, the extent to which crayfish-associated bioturbation impacts the recruitment of cyanobacteria may be significantly reduced during the mid summer owing to the reduced activity of crayfish during this period.

The highest number of crayfish captured in this study was at station $\mathrm{G}$ on 17 November when the water temperature was rapidly declining. On that day, the numbers of captures at other stations were far lower than at station G. The water temperature at station $G$ from September to November 2006 was typically a few degrees higher than at most of the other grid points set across the pond, although the factors responsible for the high temperature at this station have not been ascertained (Yamamoto \& Tsukada, unpublished data). Many crayfish were reasonably assumed to have gathered around this station owing to its warm environment. In late autumn, when the water temperature is falling, the recruitment of cyanobacteria from the sediment is assumed to occur locally at warmer points. The recruitment of cyanobacteria at such points would be promoted by bioturbation by accumulated animals. Since females represented the larger part of the captures in November, female crayfish can contribute to the extension of the bloom by their intensive bioturbation at partially warm points.

\section{CONCLUSIONS}

The wind-induced water current may be an impetus for the recruitment of cyanobacteria from sediment in a shallow pond. However, results of this study suggest the potential influence of crayfish-associated bioturbation on the dynamics of cyanobacteria in the Hirosawa-noike Pond where the recruitment of cyanobacteria from the sediment is assumed to be especially important in the formation of cyanobacterial blooms. The seasonal variation in the sex ratio of the captured crayfish has led to the hypothesis that the relationship between crayfishassociated bioturbation and the recruitment of cyanobacteria depends on crayfish sex and the season. Males contribute the most to the initiation of the bloom in spring. Conversely, females contribute to the extension of the bloom in late autumn. Both males and females contribute equally to the maintenance of the cyanobacerial bloom from the summer to autumn. The extent to which such a relationship between crayfish-associated bioturbation and cyanobacterial recruitment hold in other populations is unknown, since no analogous seasonal variation in the sex ratio of $P$. clarkii has yet been described. The extent to which crayfish-associated bioturbation contributes to the total recruitment of cyanobacteria warrants further study.

\section{ACKNOWLEDGEMENTS}

Y. Matsui is appreciated for his assistance in the field, as well as T. Knoy for revising the English in the manuscript.

\section{REFERENCES}

Anastácio, P.M., A.F. Frias \& J.C. Marques. 2000. Impact of crayfish densities on wet seeded rice and the inefficiency of a non-ionic surfactant as an ecotechnological solution. Ecol. Eng., 15: 17-25.

Angeler, D.G., S. Sánchez-Carrillo, G. GarcÍa \& M. AlvarezCobelas. 2001. The influence of Procambarus clarkii (Cambaridae, Decapoda) on water quality and sediment characteristics in a Spanish floodplain wetland. Hydrobiologia, 464: 89-98.

Barbaresi, S., E. Tricarico \& F. Gherardi. 2004. Factors inducing the intense burrowing activity of the red-swamp crayfish, Procambarus clarkii, an invasive species. Naturwissenschaften, 91: 342-345.

Barbiero, R.P. 1993. A contribution to the life history of the planktonic cyanophyte, Gloeotrichia echinulata. Arch. Hydrobiol., 127: 87-100.

Barbiero, R.P. \& E.B. Welch. 1992. Contribution of benthic blue-green algal recruitment to lake populations and phosphorus translocation. Freshwat. Biol., 27: 249-260. 
Brookes, J.D. \& G.G. Ganf. 2001. Variations in the buoyancy response of Microcystis aeruginosa to nitrogen, phosphorus and light. J. Plankton Res., 23: 1399-1411.

Brunberg, A.K. \& P. Blomqvist. 2003. Recruitment of Microcystis (Cyanophyceae) from lake sediments: the importance of littoral inocula. J. Phycol., 39: 58-63.

Burras, L., G. Blakewood, T. Richard \& J.V. Huner. 1995. Laboratory observations on burrowing in different soils by commercially important procambarid crayfish. Freshw. Crayfish, 10: 427-434.

Creed, R.P.Jr. 1994. Direct and indirect effects of crayfish grazing in a stream community. Ecology, 75: 2091-2103.

Croll, S.L. \& S.A. Watts. 2004. The effect of temperature on feed consumption and nutrient absorption in Procambarus clarkii and Procambarus zonangulus. J. World Aquac. Soc., 35: 478-488.

Dorn, N.J., P. Urgelles \& J.C. Trexler. 2005. Evaluating active and passive sampling methods to quantify crayfish density in a freshwater wetland. J. N. Am. Benthol. Soc., 24: 346-356.

Downing, J.A., S.B. Watson \& E. McCauley. 2001. Predicting cyanobacteria dominance in lakes. Can. J. Fish. Aquat. Sci., 58: 1905-1908.

Englund, G. \& J.J. Krupa. 2000. Habitat use by crayfish in stream pools: influence of predators, depth and body size. Freshwat. Biol., 43: 75-83.

Faller, M., I. Maguire \& G. Klobučar. 2006. Annual activity of the noble crayfish (Astacus astacus) in the Orljava River (Croatia). Bull. Fr. Pêche Piscic., 383: 23-39.

Feminella, J.W. \& V.H. Resh. 1989. Submersed macrophytes and grazing crayfish: an experimental study of herbivory in a California freshwater marsh. Holarctic Ecol., 12: 1-8.

Gherardi, F. \& S. Barbaresi. 2000. Invasive crayfish: active patterns of Procambarus clarkii in the rice fields of the Lower Guadalquivir (Spain). Arch. Hydrobiol., 150: 153-168.

Gherardi, F., S. Barbaresi \& S. Gabriele. 2000. Spatial and temporal patterns in the movement of Procambarus clarkii, an invasive crayfish. Aquat. Sci., 62: 179-193.

Hansson, L.A. 1996. Algal recruitment from lake sediments in relation to grazing, sinking, and dominance patterns in the phytoplankton community. Limnol. Oceanogr., 41: 1312-1323.

Hansson, L.A., L.G. Rudstam, T.B. Johnson, P. Soranno \& Y. Allen. 1994. Patterns in algal recruitment from sediment to water in a dimictic, eutrophic lake. Can. J. Fish. Aquat. Sci., 51: 2825-2833.

Havens, K.E. 1991. Fish-induced sediment resuspension: effects on phytoplankton biomass and community structure in a shallow hypereutrophic lake. J. Plankton Res., 13: 1163-1176.

Head, R.M., R.I. Jones \& A.E. Bailey-Watts. 1999. An assessment of the influence of recruitment from the sediment on the development of planktonic populations of cyanobacteria in a temperate mesotrophic lake. Freshwat. Biol., 41: 759-769.

Hirakoso, S. 2001. Burrows of Procambarus clarkii (Girard) (Decapoda: Cambaridae)-Observations in the rice field of fallow state. Earth Sci., 55: 227-239.

Huner, J.V. 2002. Procambarus. In: Holdich D.M. (Ed.), Biology of freshwater crayfish. Blackwell Science: 541-584.

Ihle, T., S. Jähnichen \& J. Benndorf. 2005. Wax and wane of Microcystis (Cyanophyceae) and microcystins in lake sediment: a case study in Quitzdorf Reservoir (Germany). J. Phycol., 41: 479-488.

Karlsson-Elfgren, I., E. Rydin, P. Hyenstrand \& K. Pettersson. 2003. Recruitment and pelagic growth of Gloeotrichia echinulata (Cyanophyceae) in Lake Erken. J. Phycol., 39: 1050-1056.

Karlsson-Elfgren, I. \& A.K. Brunberg. 2004. The importance of shallow sediments in the recruitment of Anabaena and Aphanizomenon (Cyanopheceae). J. Phycol., 40: 831-836.

Klemer, A.R., J. Feuillade \& M. Feuillade. 1982. Cyanobacterial blooms: carbon and nitrogen limitation have opposite effects on the buoyancy of Oscillatoria. Science, 215: 1629-1631.

Körner, S. \& A. Nicklisch. 2002. Allelopathic growth inhibition of selected phytoplankton species by submerged macrophytes. J. Phycol., 38: 862-871.

Matsuzaki, S.S., N. Usio, N. Takamura, N. \& I. Washitani. 2007. Effects of common carp on nutrient dynamics and littoral community composition: roles of excretion and bioturbation. Fundam. Appl. Limnol. (Arch. Hydrobiol.), 168/1: 27-38.

Nakai, S., Y. Inoue, M. Hosomi \& A. Murakami. 1999. Growth inhibition of blue-green algae by allelopathic effects of macrophytes. Water Sci. Technol. 39: 47-53.

Nyström, P. 2002. Ecology. In: Holdich, D.M. (Ed.), Biology of freshwater crayfish. Blackwell Science: 192-235.

Payette, A.L. \& I.J. McGaw. 2003. Thermoregulatory behavior of the crayfish Procambarus clarki in a burrow environment. Comp. Biochem. Physiol. A., 136: 539-556.

Pechar, L. 1992. Water blooms of Aphanizomenon flos-aquae. An ecological study of fish pond populations. Arch. Hydrobiol./Suppl., 90: 339-418.

Preston, T., W.D.P. Stewart \& C.S. Reynolds. 1980. Bloomforming cyanobacterium Microcystis aeruginosa overwinters on sediment surface. Nature, 288: 365-367.

Rengefors, K., S. Gustafsson \& A. Ståhl-Delbanco. 2004. Factors regulating the recruitment of cyanobacterial and eukaryotic phytoplankton from littoral and profundal sediments. Aquat. Microb. Ecol., 36: 213-226.

Reynolds, J.D. 2002. Growth and Reproduction. In: Holdich, D.M. (Ed.), Biology of freshwater crayfish. Blackwell Science: $152-191$.

Reynolds, C.S., G.H.M. Jaworski, H.A. Cmiech \& G.F. Leedale. 1981. On the annual cycle of the blue-green alga Microcystis aeruginosa Kütz. emend. Elenkin. Philos. Trans. R. Soc. Lond. B, 293: 419-477.

Robarts, R.D \& T. Zohary. 1987. Temperature effects on photosynthetic capacity, respiration, and growth rates of bloom-forming cyanobacteria. N. Z. J. Mar. Freshw. Res., 21: 391-399.

Rodríguez, C.F., E. Bécares \& M. Fernández-Aláez. 2003. Shift from clear to turbid phase in Lake Chozas (NW Spain) due to the introduction of American red swamp crayfish (Procambarus clarkii). Hydrobiologia, 506-509: 421-426.

Rodríguez, C.F., E. Bécares, M. Fernández-Aláez \& C. Fernández-Aláez. 2005. Loss of diversity and degradation of wetlands as a result of introducing exotic crayfish. Biol. Invasions, 7: 75-85.

Schelske, C.L., H.J. Carrick \& F.J. Aldridge. 1995. Can windinduced resuspension of meroplankton affect phytoplankton dynamics? J. N. Am. Benthol. Soc., 14: 616-630.

Smart, A.C., D.M. Harper, F. Malaisse, S. Schmitz, S. Coley \& A.-C. Gouder de Beauregard. 2002. Feeding of the exotic Louisiana red swamp crayfish, Procambarus clarkii (Crustacea, Decapoda), in an African tropical lake: Lake Naivasha, Kenya. Hydrobiologia, 488: 129-142.

Spencer, C.N. \& D.L. King. 1989. Role of light, carbon dioxide and nitrogen in regulation of buoyancy, growth and bloom formation of Anabaena flos-aquae. J. Plankton Res., 11: 283-296.

Ståhl-Delbanco, A. \& L.A. Hansson. 2002. Effects of bioturbation on recruitment of algal cells from the "seed bank" of lake sediments. Limnol. Oceanogr., 47: 1836-1843.

Ståhl-Delbanco, A., L.A. Hansson \& M. Gyllström. 2003. Recruitment of resting stages may induce blooms of Microcystis at low N:P ratios. J. Plankton Res. 25: 1099-1106.

Suko, T. 1958. Studies on the development of the crayfish. VI. The reproductive cycle. Sci. Rept. Saitama Univ. B., 3: 79-91.

Takano, K., \& S. Hino. 2000. Effect of temperature and soluble reactive phosphorus on abundance of Aphanizomenon flos-aquae (Cyanophyceae). Phycol. Res., 48: 9-13. 
Tan, X., F. Kong, H, Cao, Y. Yu \& M. Zhang. 2008. Recruitment of bloom-forming cyanobacteria and its driving factors. Afr. J. Biotechnol., 7: 4726-4731.

Taylor, C.A. 2002. Taxonomy and conservation of native crayfish stocks. In: Holdich, D.M. (Ed.), Biology of freshwater crayfish. Blackwell Science: 236-257.

Trimbee, A.M. \& G.P. Harris. 1984. Phytoplankton population dynamics of a small reservoir; use of sedimentation traps to quantify the loss of diatoms and recruitment of summer bloom-forming blue-green algae. J. Plankton Res., 6: 897-918.

Trimbee, A.M. \& E.E. Prepas. 1987. Evaluation of total phosphorus as a predictor of the relative biomass of blue-green algae with emphasis on Alberta lakes. Can. J. Fish. Aquat. Sci., 44: 1337-1342.

Tsujimura, S., H. Tsukada, H. Nakahara, T. Nakajima \& M. Nishino. 2000. Seasonal variations of Microcystis populations in sediments of Lake Biwa, Japan. Hydrobiologia, 434: 183-192.

Tsujimura, S., K. Ishikawa \& H. Tsukada. 2001. Effect of temperature on growth of the cyanobacterium Aphanizomenon flos-aquae in Lake Biwa and Lake Yogo. Phycol. Res., 49: 275-280.

Tsujimura, S. \& T. Okubo. 2003. Development of Anabaena blooms in a small reservoir with dense sediment akinete population, with special reference to temperature and irradiance. J. Plankton Res., 25: 1059-1067.

Tsukada, H. 2006. A study on the life history and the factor affecting the dominance of Microcystis in eutrophic lakes. $\mathrm{Ph} . \mathrm{D}$. thesis, Kyoto University.

Tsukada, H., S. Tsujimura \& H. Nakahara. 2006. Seasonal succession of phytoplankton in Lake Yogo over 2 years: effect of artificial manipulation. Limnology, 7: 3-14.
Verspagen, J.M.H., E.O.F.M. Snelder, P.M. Visser, J. Huisman, L.R. Mur \& B.W. Ibelings. 2004. Recruitment of benthic Microcystis (Cyanophyceae) to the water column: internal buoyancy changes or resuspension? J. Phycol., 40: 260-270.

Verspagen, J.M.H., E.O.F.M. Snelder, P.M. Visser, K.D. Jöhnk, B.W. Ibelings, L.R. Mur \& J. Huisman. 2005. Benthic-pelagic coupling in the population dynamics of the harmful cyanobacterium Microcystis. Freshwat. Biol., 50: 854-867.

Yamamoto, Y. 2009a. Environmental factors that determine the occurrence and seasonal dynamics of Aphanizomenon flos-aquae. J. Limnol., 68: 122-132.

Yamamoto, Y. 2009b. Effect of temperature on recruitment of cyanobacteria from the sediment and bloom formation in a shallow pond. Plankton Benthos Res., 4: 95-103.

Yamamoto, Y. \& H. Nakahara. 2005a. Competitive dominance of the cyanobacterium Microcystis aeruginosa in nutrient-rich culture conditions with special reference to dissolved inorganic carbon uptake. Phycol. Res., 53: 201-208.

Yamamoto, Y. \& H. Nakahara. 2005b. The formation and degradation of cyanobacterium Aphanizomenon flos-aquae blooms: the importance of $\mathrm{pH}$, water temperature, and day length. Limnology, 6: 1-6.

Yamamoto, Y. \& H. Nakahara. 2009a. Life history of cyanobacterium Aphanizomenon flos-aquae. Taiwania, 54: 113-117.

Yamamoto, Y. \& H. Nakahara. 2009b. Seasonal variations in the morphology of bloom-forming cyanobacteria in a eutrophic pond. Limnology, 10: 185-193.

Yamamoto, Y. \& H. Tsukada. 2009. Measurement of in situ specific growth rates of Microcystis (cyanobacteria) from the frequency of dividing cells. J. Phycol., 45: 1003-1009.

Received: May 2009

Accepted: October 2009 